\title{
Removal Color Study of Azo dye (4-4'-antipyriyl azo 4-Amino Phenol) from Aqueous Solution by using Photo - Fenton Oxidation
}

\author{
Received : 7/12/2017 \\ Asaad Hassoun Saleh Ghanim Al - \\ Olawi* \\ ahs772001@yahoo.com
}

Accepted : 18/1/2018

\author{
Dunia Yousif Fanfoon Al-Rammahi * \\ asildrm81@gmail.com \\ *Ministry of Education - Directorate of Education \\ Qadisiyah
}

\begin{abstract}
$\underline{\text { Abstract }}$
Advanced oxidation processes are extensively used for the removal of organic constituents from water and wastewater. The aim of this study was to show the parameters the effects of initial dye concentration, hydrogen peroxide dosage, $\mathrm{pH}$, and Fenton reagent of azo dye. It has been found that the removal rate increased as the initial concentration of $\mathrm{H}_{2} \mathrm{O}_{2}$ and ferrous ion increase to optimize value. The degradation with $\mathrm{UV} / \mathrm{H}_{2} \mathrm{O}_{2} / \mathrm{Fe}^{2+}$ system was the fastest. The degradation is fast with $\mathrm{UV} / \mathrm{H}_{2} \mathrm{O}_{2} / \mathrm{Fe}^{2+}$ system. The best results were obtained from photo Fenton's reagent with efficiency more than $99 \%$ at $\mathrm{pH}=6.5,\left[\mathrm{H}_{2} \mathrm{O}_{2}\right]=300 \mathrm{mg} / \mathrm{L},\left[\mathrm{Fe}^{2+}\right]=150 \mathrm{mg} / \mathrm{L}$. The concentration of undegraded dye was detected by using parameters at $\lambda_{\max }=391 \mathrm{~nm}$.
\end{abstract}

Key words: Photo - Fenton Oxidation, Removal, Azo dye, UV-Visible.

\section{1- Introduction}

The environmental the danger of the liquid waste of Textile and yarn factories wastewater industry are the major source of water and contaminants in groundwater. Azo dyes constitute the largest class of dyes which is used in several industries[1], as well as for colored solvents, inks, paints, food, paper, plastic, rubber, varnishes, cosmetics, and drugs [2]. One of these risks is vehicles that carry high colors, high level of COD, large ranges of $\mathrm{pH}$ neutral, and which resist natural degradation. For instance fabric dying disposed 100-170 L of colored effluents per $\mathrm{Kg}$ of cloth processed[3]. Due to high efficiency in the removal of the most poisonous in particular environmental pollutants used Photo-oxidation technique for that purpose [4].The development of advanced oxidation processes (AOPs) is an attempt to take advantage of the speed and time at work, the nonselective reactivity of the $(\mathrm{OH})$. AOPs are defined as those techniques that include the generation of highly reactive radical intermediates, particularly the $(\mathrm{OH})$ at ambient temperature. The advantages of $\mathrm{AOP}_{\mathrm{S}}$ are their high treatment capability, rapid reaction rates, hence relatively small reactors, high elasticity and the possibility of mixing them into water recycling processes [5], [6] Generation of hydroxyl radicals ( $\mathrm{OH}$ ) from hydrogen peroxide this process is called Fenton reaction and is based on an electron transfer between $\mathrm{H}_{2} \mathrm{O}_{2}$ and iron ions conduct as homogeneous catalyst[7],[8]. This method provides effective hydroxyl radical at the lowest cost, using easy-to-handle reagents. Some industrial wastewater contains aromatic amines and Fenton reagent an effective way to treat 
these substances [9], a wide range of dyes [10], and many other substances, such as. Repeller[11],[12] and corrosion inhibition [13],[14]. The antipyrine azo dyes (Table 1) was prepared according to the equations[15] (scheme1). Using various advanced oxidation processes various reaction conditions under UV light.

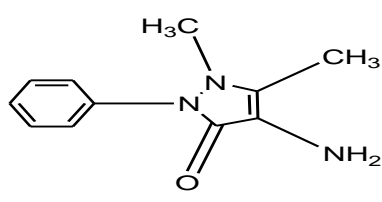

4 -Amino antipyrine<smiles>[X]c1ccc(O)c(N=Nc2c(C)n(C)n(-c3ccccc3)c2=O)c1</smiles>

4-4-antipyriyl azo 4- X phenol
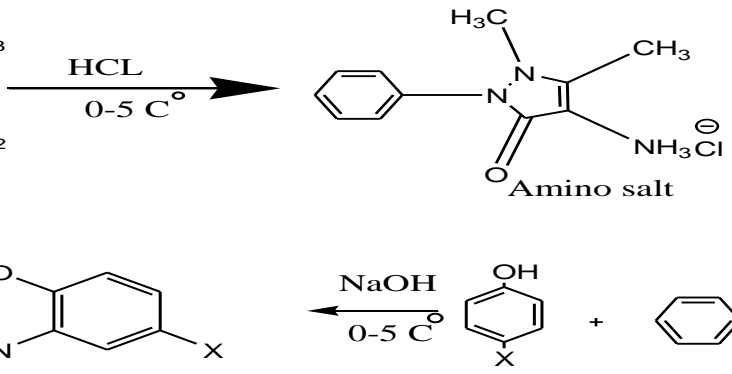

4-X phenol
All chemicals were used without further purification. Ferrous chloride $\left(\mathrm{FeCl}_{2}\right)$, Hydrogen peroxide $\left(\mathrm{H}_{2} \mathrm{O}_{2} 30 \%\right.$ w/v),Hydrochloric $\operatorname{acid}(\mathrm{HCL})$ and sulphuric acid $\mathrm{H}_{2} \mathrm{SO}_{4}$ Sodium hydroxide and $(\mathrm{NaOH})$ were supplied from $\mathrm{BDH}$. Distilled water is used to prepare all the chemicals and solutions.

\subsection{Instruments}

UV-Visible 7804 C spectrophotometer (Sunny, China) was used to measure the maximum absorbance of dye solutions at $1 \mathrm{n}$ $\mathrm{m})$.

$$
\mathrm{X}=\mathrm{Br}, \mathrm{CL}, \mathrm{NH} 2
$$

Scheme (1) :preparation of dyes.

4-4'-antipyriyl
azo 4-Amino
Phenol
(4AANH 2$)$
(E)-4-((5-amino-
2-hydroxyphenyl)
diazenyl)-1,5-
dimethyl-2-
phenyl-1,2-
dihydropyrazol-3-
one

Table 1 : antipyrine azo dyes

\section{2- Materials and methods}

\subsection{Materials and Reagents}

UV-Visible 1650 spectrophotometer

(Shimadzu ,Japan) was used to recording the absorption spectra of aqueous solutions of dye. The temperature was adjusted by using regulator water bath WB (Optima). The $\mathrm{pH}$ was measured by using a microprocessor $\mathrm{pH}$ meter 211, (Hanna ,Romania) instruments.

\subsection{Irradiation of dye solutions}

All dye solutions were irradiated for duration of 80 minutes (the most of dye molecules were degraded or become colorless 


\section{AL-Qadisiyah Journal of pure Science $\quad$ Vol.23 No. $1 \quad$ Year 2018}

at the time near to this period). Within this time samples were taken by syringe for measuring the dye ahsorntion at $\lambda=391 \mathrm{~nm}$ and then
Ferrous ion at the range $(20-100 \mathrm{mg} / \mathrm{L})$ at the $\mathrm{pH}$ equal of 6.5 and $298 \mathrm{~K}$. Another series of solutions were nrenared hy mixing $\mathrm{Fe}^{+2}$ (100
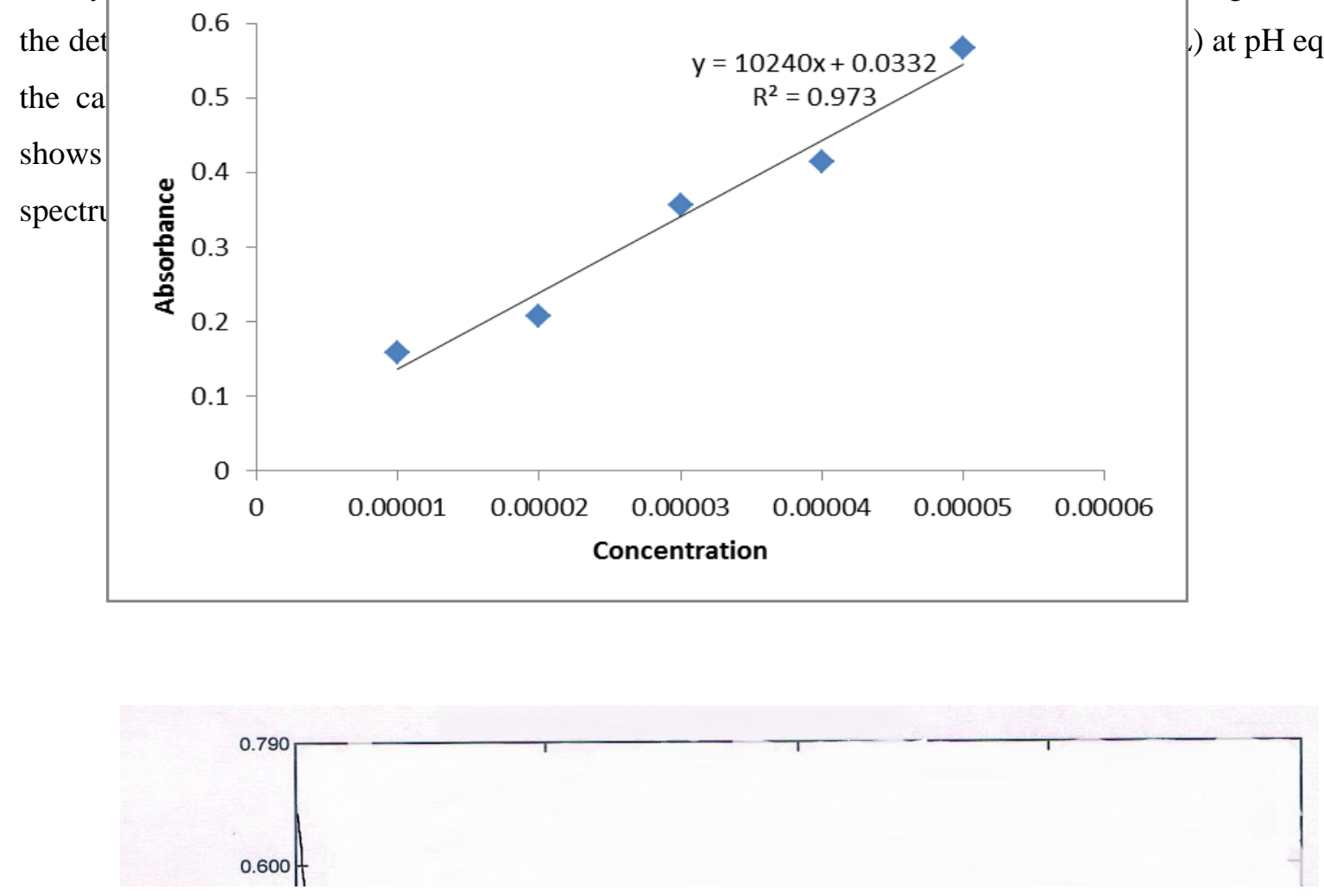

Figure(2): Calibration curve for $4 \mathrm{AANH}_{2}$ dye concentration $1 \times 10^{-5} \mathrm{M}$ at $\mathrm{pH}=6.5, \mathrm{~T}=298 \mathrm{~K}$

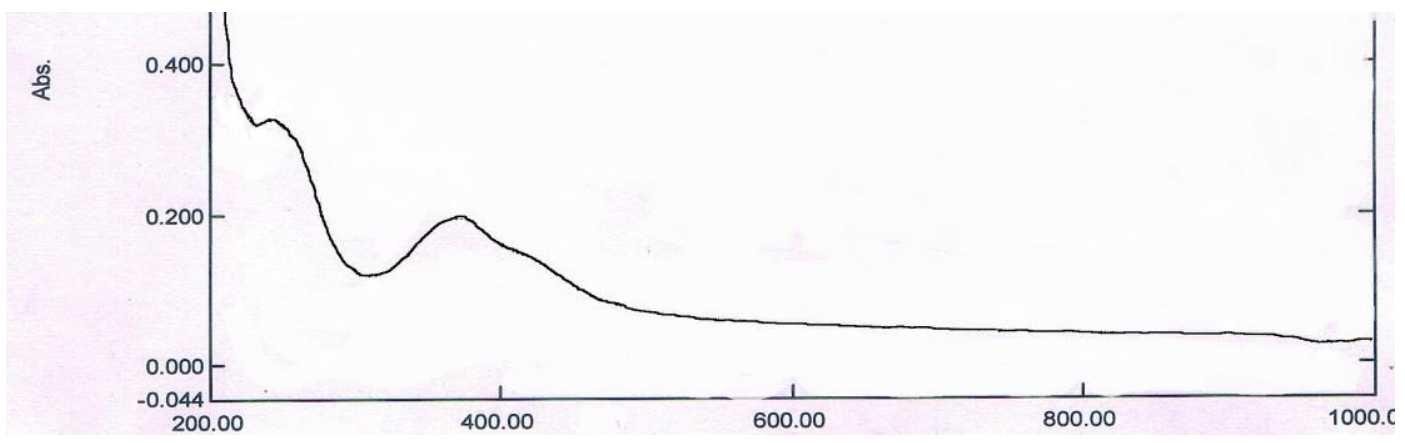

Figure (3): UV-Visible spectrum of aqueous solution of $4 \mathrm{AANH}_{2}$ dye concentration $1 \times 10^{-5} \mathrm{M}, \mathrm{pH}=6.5$, $\mathrm{T}=293 \mathrm{~K}$.

\subsection{Fenton's system}

A series of Fenton's solutions were prepared by mixing $\mathrm{H}_{2} \mathrm{O}_{2}(100 \mathrm{mg} / \mathrm{L})$ and solution were prepared by using $\mathrm{Fe}^{+2}(150$ $\mathrm{mg} / \mathrm{L})$ and $\mathrm{H}_{2} \mathrm{O}_{2}(100 \mathrm{mg} / \mathrm{L})$ at $\mathrm{pH}=(1-8)$ and 298K. In all the above solutions, the dye 
concentration was $3 \times 10^{-5} \mathrm{M}$. All the solutions were irradiated for $\mathbf{8 0}$ minutes [16],then measuring the concentration was determined by measuring the dye absorbance at $\lambda_{\max }=391 \mathrm{~nm}$.

\section{3- RESULTS AND DISCUSSION}

\subsection{The effect of initial dye concentration}

In Figure (4) for 4AANH2 dye at $\mathrm{pH}=6.5$ show effect of different dye concentrations on the degradation of azo dye using UV irradiation for 80 minutes, $\mathrm{T}=298 \mathrm{~K}$. It has found that increasing the initial concentration from $1 \times 10^{-5} \mathrm{M}$ to $5 \times 10^{-5} \mathrm{M}$ and because of decreasing penetration of photons entering into the solution and larraring tha farmation of
Figure(5): Relationship between $\log \mathrm{R}$ and $\log \mathrm{C}$ from ox $\mathrm{pH}=6.5, \mathrm{~T}=298 \mathrm{~K}$.

first order with respect to dye concentration that the photooxidation reactions to the $4 \mathrm{AANH}_{2}$ dye .The law empirical method used to calculate the rapidity of reaction can be related with the absorption of the dye [18]. To calculate the order of reaction, the drawing was between $\log \mathrm{R}$ and $\log \mathrm{C}$ and show in Fioure(5) To calculate the order of reaction the

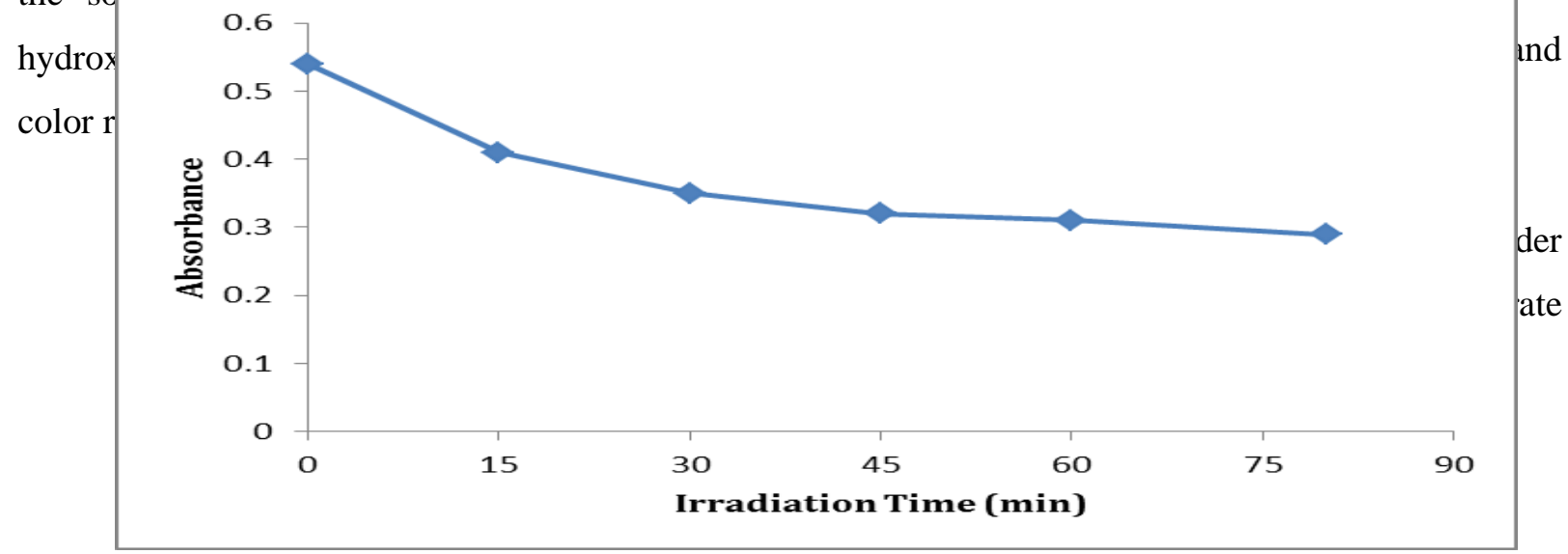

Figure(4): Effect of Irradiation time on Color removal , $[4 \mathrm{AANH} 2]=3 \times 10^{-5} \mathrm{M}, \mathrm{pH}=6.5, \mathrm{~T}=298 \mathrm{~K}$

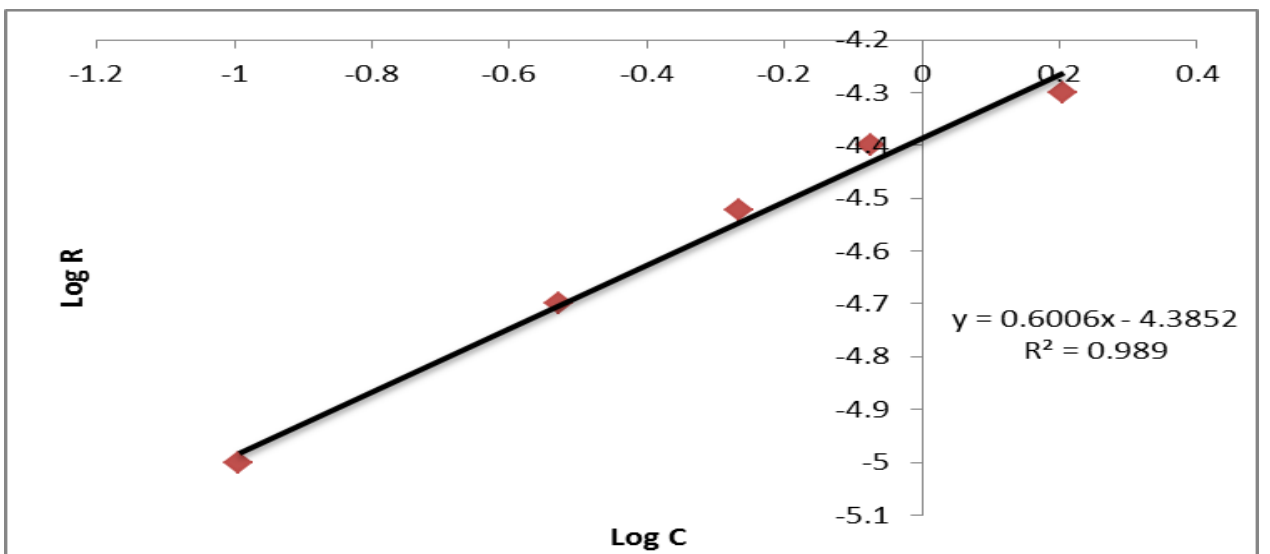




\section{AL-Qadisiyah Journal of pure Science $\quad$ Vol.23 No. $1 \quad$ Year 2018}

\subsection{Fenton's system}

\subsubsection{Effect of initial Ferrous ion concentration}

The rate of the degradation by $\mathrm{H}_{2} \mathrm{O}_{2}$ alone is very low for many dyes, especially azo dyes, addition of $\mathrm{Fe}^{+2}$ fast the generation of hydroxyl radical $(\mathrm{OH})$ [19].Figure (6) shows the effect of photo Fenton's reagent on the decolourization of azo dyes as a function of UV irradiation time for various concentrations of ferrous ion in the range $50-150 \mathrm{mg} / \mathrm{L}$ in the presence of a fixed concentration of $\mathrm{H}_{2} \mathrm{O}_{2}$ $(300 \mathrm{mg} / \mathrm{L})$ for $\mathbf{8 0}$ minutes. The best finding was reached $97.8 \%$ of color removal by $\mathrm{Fe}^{+2}$ $/ \mathrm{H}_{2} \mathrm{O}_{2} / \mathrm{UV}$ used $\left[\mathrm{H}_{2} \mathrm{O}_{2}\right]=300 \mathrm{mg} / \mathrm{L},\left[\mathrm{Fe}^{2+}\right]=150$ $\mathrm{mg} / \mathrm{L}$, with the increasing concentration of $\mathrm{Fe}^{+2}$, $\mathrm{H}_{2} \mathrm{O}_{2}$ the percent of color removal increased after 80 minutes of reaction time. The mechanism of the Fenton process is reported below[20],[21].

$$
\begin{aligned}
& \mathrm{Fe}^{2+}+\mathrm{H}_{2} \mathrm{O}_{2} \rightarrow \mathrm{Fe}^{3+}+\mathrm{OH}^{-}+\mathrm{HO}^{\bullet} \\
& \mathrm{Fe}^{3+}+\mathrm{H}_{2} \mathrm{O}_{2} \rightarrow \mathrm{Fe}^{2+}+\mathrm{H}^{+}+\mathrm{HO}_{2}^{\cdot} \\
& 2 \mathrm{H}_{2} \mathrm{O}_{2} \rightarrow \mathrm{HO}^{\circ}+\mathrm{HO}_{2}+\mathrm{H}_{2} \mathrm{O}(1-4)
\end{aligned}
$$

Figure(6): Effect of different $\mathrm{Fe}^{+2}$ concentration on the color remova

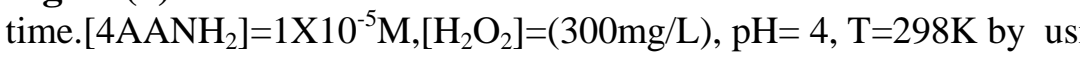

conditions is due to more hydroxyl radical ${ }^{\circ} \mathrm{OH}$ generate, because $\mathrm{Fe}^{+2}$ ions rapidly oxidized to $\mathrm{Fe}^{+3}$ ions formation $\mathrm{Fe}(\mathrm{OH})_{3}$ the color removal at basic conditions is low.

\section{$\underline{\text { 3.2.2 Effect of initial } \mathrm{H}_{2}} \underline{\mathrm{O}}_{2}$ concentration}

The concentration of hydrogen peroxide $\mathrm{H}_{2} \mathrm{O}_{2}$ in Fenton systems has an important role in the degradation of azo dye. As it observed through experiments that were carried out using changing concentrations of $\mathrm{H}_{2} \mathrm{O}_{2}$ ranging (100-300 $\mathrm{mg} / \mathrm{L})$ at a constant concentration of ferrous ion $(150 \mathrm{mg} / \mathrm{L})$.Also, the $\mathrm{H}_{2} \mathrm{O}_{2}$ dosages increasing the removal percentage of color increased from $97.5 \%$ to $99.1 \%$.

Figure (7) shows the color removal of $4 \mathrm{AANH}_{2}$ as a function of UV irradiation time for various initial $\mathrm{H}_{2} \mathrm{O}_{2}$ dosages. Therefore the increasing of hydrogen peroxide concentration the ratio of degradation of pollutants increases because of increase quantity of generating hydroxide radicals and

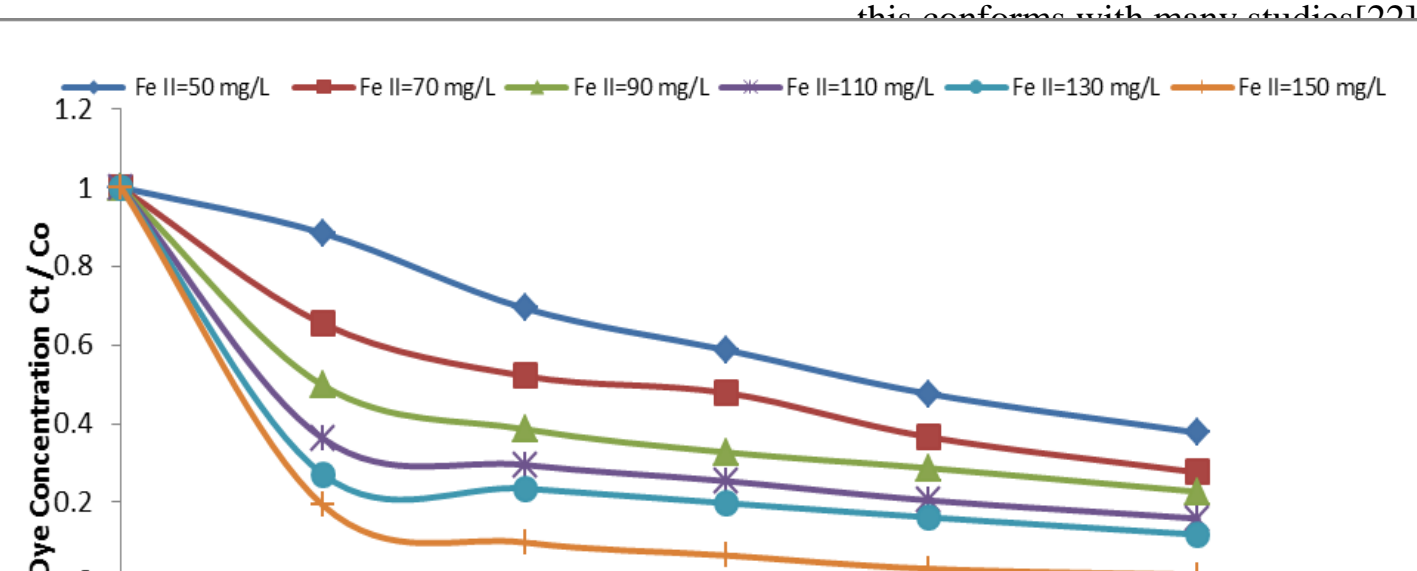




\section{AL-Qadisiyah Journal of pure Science $\quad$ Vol.23 No. $1 \quad$ Year 2018}

decreased as the $\mathrm{pH}$ value increased under UV irradiation.

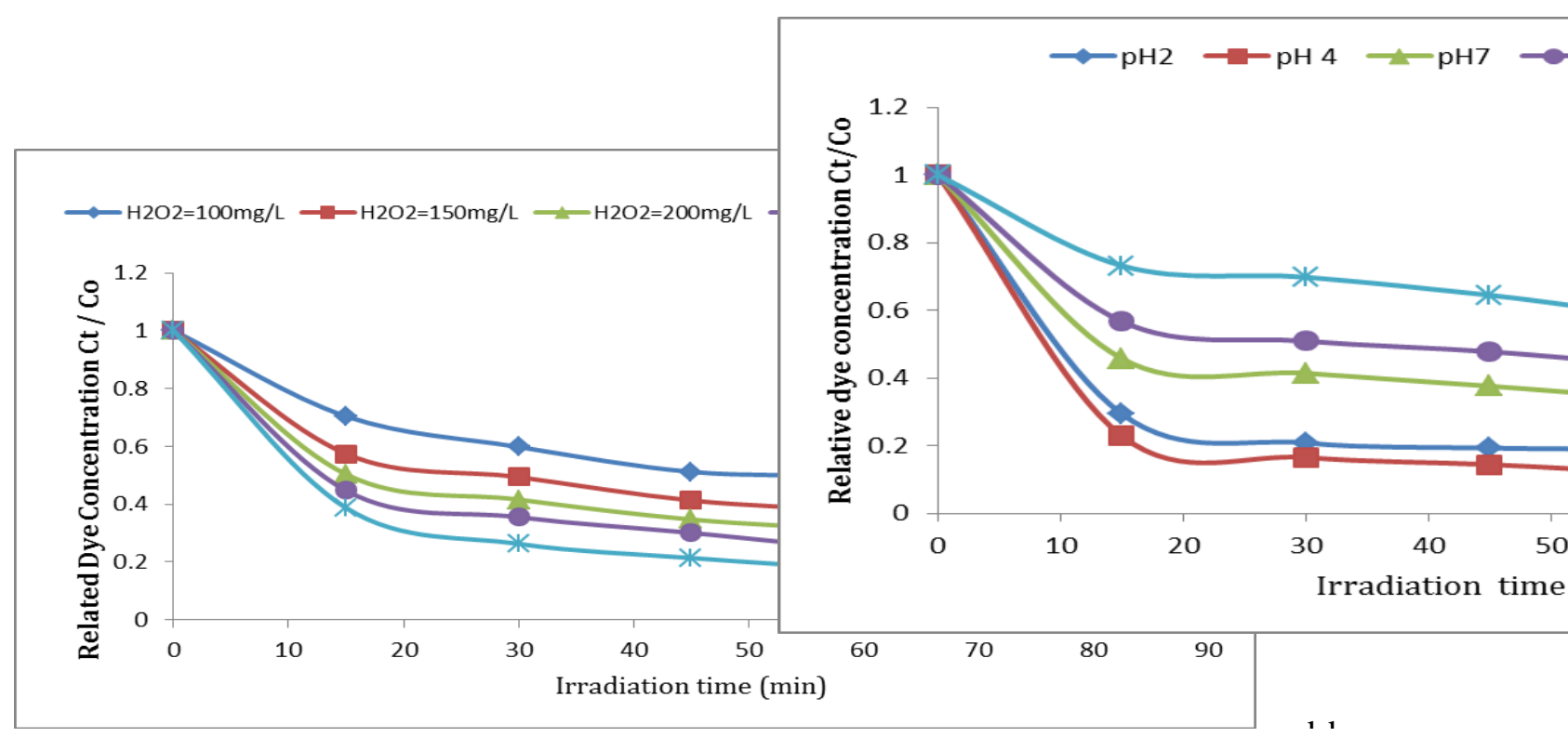

Figure(7): Effect of different initial $\mathrm{H}_{2} \mathrm{O}_{2}$ concentration on the color removal from $4 \mathrm{AANH}_{2}=1 \mathrm{X} 10^{-5} \mathrm{M}$, $\left[\mathrm{Fe}^{+2}\right]=(150 \mathrm{mg} / \mathrm{L}),\left[\mathrm{H}_{2} \mathrm{O}_{2}\right]=(300 \mathrm{mg} / \mathrm{L}), \mathrm{pH}=4, \mathrm{~T}=298 \mathrm{k}$ by using $\mathrm{UV} / \mathrm{H}_{2} \mathrm{O}_{2} / \mathrm{Fe}^{+2}$ method.

initial aye concentration .

\subsubsection{Effect of initial pH}

The higher ratio color removal of $4 \mathrm{AANH}_{2}$ dye was obtained under acidic media at $\mathrm{pH}=4$ under UV light and decreasing the ratio in basic media. The low color removal in basic conditions (due to $\mathrm{Fe}(\mathrm{OH})_{3}$ formation) because $\mathrm{Fe}^{+2}$ ions rapidly oxidized to $\mathrm{Fe}^{+3}$ ions formation $\mathrm{Fe}(\mathrm{OH})_{3}$ and this conforms with many studies and high color removal was obtained under acidic media (due to more $\mathrm{OH}$ adical generation)[24],[25]. Figure(8) refers the relation dye concentration $\mathrm{Ct} / \mathrm{Co}$ was
2. The study showed the speed of degradation is reduced when the increasing the concentration of the dye, due reduce the ability of light penetration when high concentrations of the dyes and lead to reduce the speed of the degradation and the color removal of dyes.

3. In the presence of Fenton's reagent and at pH media (6.5) were achieved Higher efficiencies in color removal, and high capacity were observed by increasing the concentration of $\mathrm{Fe}^{+2}$. 
Figure(8): Effect of different $\mathrm{pH}$ value of color removal from azo dye as a function of irradiation time, $\left[4 \mathrm{AANH}_{2}\right]=1 \mathrm{X} 10^{-5} \mathrm{M},\left[\mathrm{Fe}^{+2}\right]=(150 \mathrm{mg} / \mathrm{L}),\left[\mathrm{H}_{2} \mathrm{O}_{2}\right]=(300 \mathrm{mg} / \mathrm{L}), \mathrm{pH}=4, \mathrm{~T}=298 \mathrm{~K}$, using $\mathrm{UV} / \mathrm{H}_{2} \mathrm{O}_{2} / \mathrm{Fe}^{+2}$ method.

1- Shu, $\mathrm{H}$ and Huang, C. (1995).

Degradation of commercial azo

dyes in water using ozonation

and UV enhanced ozonation

process. Chemosphere. 31,

3813.

2- Guendy, H.R. (2010). Removal

of Azo Reactive, Direct Dyes from

Wastewater using Different

Coagulants at Different $\mathrm{pH}, \mathrm{J}$. Of

Applied Sci. Research,6,8,965-

963.

3- Attia, A., Kadhim, S. And

Hussein, F.(2008) .Photocatalytic

Degradation of Textile Dyeing

Wastewater Using Titanium

Dioxide and Zinc Oxide, E-J.

Chem., 5, 219-223.

4- Al-Kadasi,A.,Idris,A.,Saed,K. and

Guan, G.T.(2004). Treatment of

Textile Wastewater by Advanced

Oxidation Processes-A Review,

Global Nest: Int. J. ,6,3,222-230

5- Shashank, S. Alok, S. Satyam ,M

and Gurdeep, S. (2011). tor I reatment of I extlle and Dye

Wastewater: A Review,

International Conference on

Environmental Science and

Development, 4.

6- Bidgar ,J. ( 1995). Consider

Fenton chemistry for wastewater

treatment. Chem. Engineering

Progress. 91, 12,62 .

7- Lucking, F. Koser, H. Jank, M.

and Ritter, A. (1998). Iron

powder, graphite and activated

carbon as catalysts for the

oxidation of 4-chlorophenol with

hydrogen peroxide in aqueous

solution. Wat. Res. 32, 2607.

8- Casero, I. Sicilia, D. and Rubio,

S. (1997). Chemical degradation

of aromatic amines by Fenton's

reagent. Wat. Res. 31.

9- Kuo,W.G.(1992).Decolorizing

dye wastewater with Fenton's

reagent. Wat. Res. 26, 881,

10- Nam, S. Renganathan, V.,

Tratnyek, P. G.(2001). 
Substituent effects on azo dye oxidation by the Fe III-EDTA$\mathrm{H}_{2} \mathrm{O}_{2}$ system. Chemosphere. 45, 59.

11- Huston, P. and Pignatello, J. (1999). Degradation of selected pesticide active ingredients and commercial formulations in water by the photo-assisted Fenton reaction. Wat. Res. 33, 1238,.

12- Barbusinski, K. and Filipek, K.(2001). Use of Fenton's reagent for removal of pesticides from industrial wastewater. Polish J. Envir. Studies, 10, 207.

13- Lin, S. Lin, C. and Leu, H.(1999). Operating characterristics and kinetic studies of surfactant wastewater treatment by Fenton oxidation. Wat. Res. 33, 1735.

14- Shu, H. and Huang, C. (1995). Degradation of commercial azo dyes in water using ozonation and UV enhanced ozonation process.

Chemosphere. 31, 3813.

15- Hussain. J. M, Azhar. Y and Hayder. A.(2011). Determination of trace amount of $\mathrm{Pd}(\mathrm{II})$ and
$\mathrm{Ni}(\mathrm{II})$ with newly synthesized pyrozeone azo bromophenol by spectrophotometric methods EJournal of Chem. 8 (51), 425433.

16- Pignatello, J. J., Oliveros, E., MacKay, A. (2006). Advanced Oxidation Processes for Organic Contaminant Destruction Based on the Fenton Reaction and Related Chemistry, Critical Rev. Environ. Sci. Technol., 36, 1 84 .

17- Rezaee, A., Ghanaian, M. T., Hashemian, S. J., Moussavi, G., Khavanin, A. and Ghanizadeh, G.(2008). Decolorization of Reactive Blue 19 dye from textile wastewater by the UV/ $\mathrm{H}_{2} \mathrm{O}_{2}$ process, $J$. App., Sci, 8,1108-1122. 18- Lomora, M., Draghici, C. and Al. Enesca .(2001). Intermediary Compounds in Advanced Processes for Wastewater Treatment, Eng. Sci., 4, 51-58.

19- Yasar,A.,Ahmed,N.,khan,A.A.A .,khan,H.and khalid,M. (2007). 
Kinetics of UV,Fenton and

photo Fenton Processes for

Decolorization of Various Red

CL-5B Dye concentrations, J.

Appl. Sci., 7(16), 2339-2344.

20- Legrini, O., Oliveros, E. and

Braun,A.M.(1993).

Photochemical process for water

treatment, Chem. Rev., 93, 671-

698.

21- Neyens, E. and Baeyens, J .

(2003). A review of classic

Fenton's Peroxidation as an

Advanced Oxidation Technique ,

J.Hazar .Mater., B98,33-58.

22- Galindo,C. and. Kalt, A.

(1998) .UV/ $\mathrm{H}_{2} \mathrm{O}_{2}$ oxidation of monoazo dyes in aqueous

media : a kinetic study. Dyes

and Pigm., 40, 27-35.

23- Abdullah, S.B. (2008). M.Sc.

Thesis, University of Technology,

Malaysia.

24- Perez, M. Torrades, F. ,

Domenech, X. and Peral,

J.(2002). Fenton and photo

Fenton oxidation of textile

effluents, Water Res.,36: 2703-

2710.

25- Obies,M.(2011). Photocatalytic

Decolorization of Bismarck Brown

R,MScThesis, Chemistry Department, College of Science, Babylon University, Iraq.

أحدى طرق ازالة الملوثات العضوية الموجودة في مياه التصريف للمعامل الصناعية تتم بإستخدام عمليات الأكسدة المتقدمة ( AOP 'S

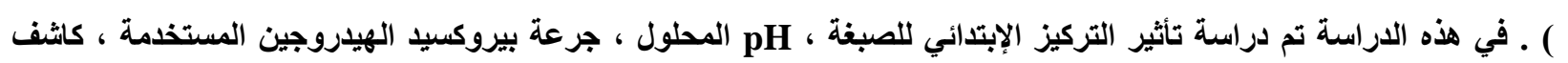

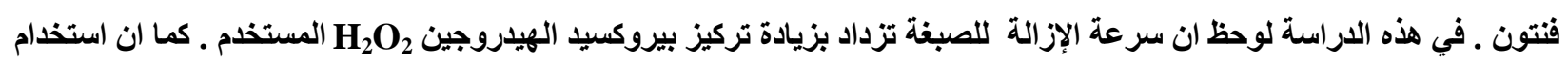

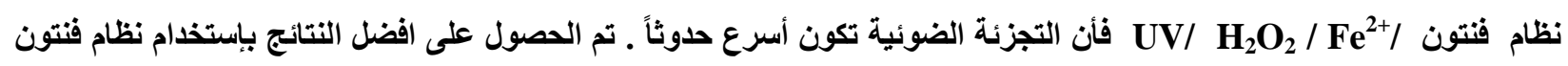

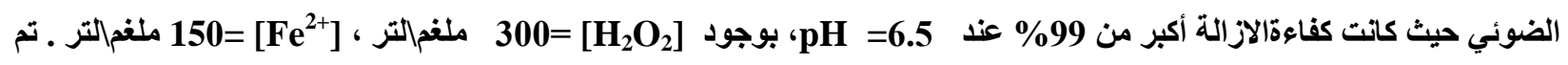
استخدام المطياف لغرض قياس تركيز الصبغة غير المتحطمة وذلك عند امتصاص محلولها المائي الأعظم ( 
